ppi $201502 Z U 4645$

Esta publicación cientifica en formato digital es continuidad de la revista impresa ISSN-Versión Impresa 0798-1406 / ISSN-Versión on line 2542-3185Depósito legal pp

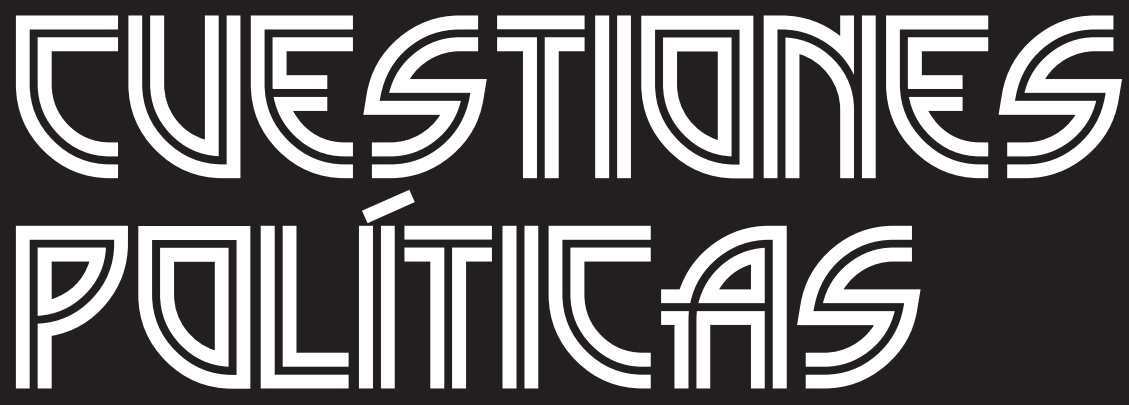

Instituto de Estudios Políticos y Derecho Público "Dr. Humberto J. La Roche' de la Facultad de Ciencias Jurídicas y Políticas de la Universidad del Zulia Maracaibo, Venezuela
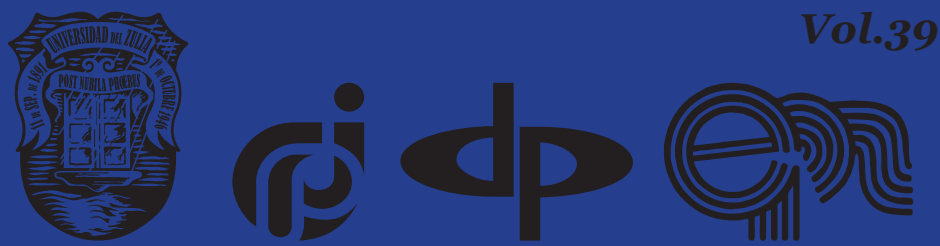


\title{
Institution of Complicity in a Crime: Comparative-Legal Interpretation
}

\author{
DOI: https://doi.org/10.46398/cuestpol.3968.33
}

\author{
Gennady Nazarenko * \\ Alexandra Sitnikova ** \\ Andrey Baybarin ***
}

\begin{abstract}
The objective of the study was to identify the design patterns and distinctive features of the institution of complicity in a crime in certain criminal laws. The methodology was based on the use of legislative interpretation operations and techniques such as the hermeneutics of criminal texts, which allows to identify the structural, constructive, and substantive features of the rules on complicity in a crime. The scientific novelty of the work lies in the textological approach of the criminal-legal regulations of the institution of complicity. This approach allows to interpret the standards in a comparative aspect, taking into account the deep level of their construction. Among the results obtained are:(1) the inclusion of complicity rules in other criminal law institutions is an unjustified design technique; (2) the absence of a complex of titles in the institution of complicity reduces the level of quality of this institution; (3) the presence of definitive rules in the institution of complicity significantly increases its quality; (4) the differentiation of accomplices in crime should not be excessive and arbitrary; (5) the rules on attempted complicity in a crime increase the preventive potential of
\end{abstract} criminal law.

Keywords: institution of complicity in a crime; criminal design traits; differentiation of accomplices; innovative legislative and textual approach; comparative legal interpretation.

Department of Criminal Law of the Southwest State University, Kursk, Russian Federation. ORCID ID: https://orcid.org/oooo-0001-7572-5100.

** Department of Criminal Law of the Southwest State University, Kursk, Russian Federation. ORCID: https://orcid.org/oooo-0002-1622-2797.

*** Department of Criminal Law of the Southwest State University, Kursk, Russian Federation. ORCID: https://orcid.org/oooo-0oo1-9183-3101. 


\section{Institución de la complicidad en un delito: interpretación jurídica comparada}

\section{Resumen}

El objetivo del estudio fue identificar los patrones de diseño y rasgos distintivos de la institución de la complicidad en un delito en las ciertas leyes penales. La metodología se basó en el uso de operaciones y técnicas de interpretación legislativa como la hermenéutica de los textos penales, lo que permite identificar los rasgos estructurales, constructivos y sustantivos de las normas sobre complicidad en un delito. La novedad científica del trabajo radica en el abordaje textológico de la normativa penallegal de la institución de la complicidad. Este enfoque permite interpretar las normas en un aspecto comparativo, teniendo en cuenta el nivel profundo de su construcción. Entre los resultados obtenidos destacan: 1) la inclusión de las normas sobre complicidad en otras instituciones de derecho penal es una técnica de diseño injustificada; 2) la ausencia de un complejo de títulos en la institución de la complicidad reduce el nivel de calidad de esta institución; 3) la presencia de normas definitivas en la institución de la complicidad aumenta significativamente su calidad; 4) la diferenciación de cómplices en el delito no debe ser excesiva y arbitraria; 5) las normas sobre tentativa de complicidad en un delito aumentan el potencial preventivo de la legislación penal.

Palabras clave: institución de la complicidad en un delito; rasgos de diseño de la penal; diferenciación de cómplices; enfoque legislativo y textual innovador; interpretación jurídica comparativa.

\section{Introduction}

A crime that is recognized as a complex social phenomenon may be committed by an individual or several individuals. The problem of complicity is one of the key issues in criminal law. There is no doubt about the need to reform legislation concerning the technological revolutions taking place in recent years, which have a direct impact on all spheres of life in society (Kirillova et al., 2020), as well as political, cultural, social, and economic changes.

Complicity is one of the most important institutions of criminal law and, at the same time, the most complex in the framework of law enforcement. Complicity is a special phenomenon in criminal activity when several individuals combine their efforts to achieve a single socially dangerous result (Suonpää et al., 2020). As can be seen from the definition, the main criterion by which complicity may be identified is the presence of willful guilt 
of all participants in the commission of a crime. Each accomplice realizes the socially dangerous nature of the act, foresees criminal consequences, and wishes or deliberately allows them, pursuing criminal goals and having common intentions. At present, based on the analysis of the norms on the institution of complicity in criminal law, it can be concluded that it is important to apply it correctly. The theory and practice of criminal law know various forms of joint participation of several persons in criminal activity - complicity, indirect execution (or infliction), careless complicity, involvement in a crime, joint participation in a crime of persons in the absence of joint intent (mutual awareness) between them (Gunadi, 2020).

The value of the institution of complicity lies in ensuring effective criminal legal protection of public relations from group criminal encroachments, as well as creating an effective legal mechanism for the individualization of responsibility and punishment of members of criminal groups. Based on the above, it should be recognized that one of the strategic directions of modern criminal law policy is to further improve the legislative structures of the institutions of complicity in the criminal laws of states to counteract group crime more effectively.

\section{Methods}

The legal method was used in this study, including legal and technical methodology and methods of interpretation of the law. The legal and technical method was used in the analysis of rulemaking. The system of the code and each of its articles must comply with certain rules for constructing the disposition and sanction of norms to be clear, direct, and logically consistent. The interpretation of the law is possible in the way of understanding the meaning and legal form - grammatical, logical, and comparative and in terms of volume - authentic, expansive, and restrictive.

The criminal-statistical method was widely used, which is characterized as the knowledge of the qualitative originality of criminal-legal phenomena and concepts through quantitative indicators. This method was used to generalize and quantify, for example, norms, their dispositions and sanctions, the structure of punish ability, and criminal records.

The study used a systematic method that allowed researching criminal law phenomena and concepts as systems, i.e., an integral set consisting of subsystems and elements. The method was used in the analysis of lawmaking, law enforcement and construction theory, knowledge, application of such system institutions as criminal law, principles of law, crime, guilt, multiple crimes, complicity, exemption from criminal liability, and punishment. The principle of consistency should correspond to the location of sections, chapters, and norms in the text of the code. The criminal code is the macro system. The microsystem is a norm, the disposition of which describes the corpus delicti, and the sanction is the type and amount of punishment. 
An important place was given to the comparative-jurisprudential (comparative) method, which was used when comparing the codes of various legal systems and states.

\section{Results}

The use of the comparative-legal method of researching the legislative structures of institutions of complicity in the criminal laws of states makes it possible to note the features of the design of the corresponding criminal law regulations (Troncoso and Weber, 2020). These features are correlated with several requirements of legislative technique and legal textology:

1. Institutions of complicity structure. The legislative practice of structuring the institutions of complicity in the criminal codes of states is very different:

- the norms on complicity are presented in the Criminal Code of the Federal Republic of Germany in the form of an independent institution "Execution, incitement, aiding and abetting", the Criminal Code of the Netherlands "Participation in a criminal offense", the Criminal Code of the Republic of Bulgaria "Complicity", the Criminal Code of Japan "Complicity", the Law of the Republic of Iran "Co-executors and accomplices of a crime", the Criminal Code of Spain "Persons subject to criminal liability for crimes and misdemeanors", and the Criminal Code of China "Complicity in a crime";

- in conjunction with the rules on preparation and attempt, the rules on complicity are grouped in the criminal laws of the Republic of Poland "Forms of committing a crime" and Denmark "Attempt and complicity".

- the rules on complicity are in one chapter with the general criminal law provisions (Criminal Code of France "General provisions").

Rulemaking recognizes the structure of the institution as a source of information creation of the institution itself. The inclusion of rules on complicity in chapters containing rules of a general nature or other institutions is an unjustified method of constructing criminal law institutions (Boduszek et al., 2020). At the same time, clarity of presentation is violated, and differentiation of legal prescriptions is difficult; there is a confusion of norms that are different in their legal nature and an unclear expression of legislative intent.

2. Article titles. Lawmakers of different states have different attitudes towards the article titles: 
Gennady Nazarenko, Alexandra Sitnikova y Andrey Baybarin
524 Institution of Complicity in a Crime: Comparative-Legal Interpretation

- article titles containing provisions on complicity are available in the Criminal Code of the Federal Republic of Germany, the Criminal Code of Japan, and the American states of New York and Pennsylvania;

- article titles are absent in the Criminal Code of the Republic of Poland, the Criminal Code of Denmark, the Criminal Code of the Netherlands, the Criminal Code of the Republic of Bulgaria, the Criminal Code of Spain, the Criminal Code of France, the Law of the Republic of Iran, and the Criminal Code of China.

From the standpoint of legislative technique, as well as criminal law textual criticism, article titles improve the structure of the law, facilitate the finding of the necessary norms, their interpretation, and comparison with each other, and discipline the drafters of the norms. The absence of article titles hinders quick access to the necessary information about the structure of the criminal law, the system relations of its institutions and criminal law regulations, their mutual location, and content (Fernández-Campoy and Aguilar-Parra, 2017).

3. Articles structuring. An analysis of the criminal legislation of states indicates that there is an ambiguous approach to the rubrication of prescriptions in lawmaking practice within the framework of articles and paragraphs. Legislators use a variety of ways to structure articles:

- articles are divided into parts in the Criminal Codes of the Netherlands, Spain, and the Republic of Bulgaria.

- criminal-legal regulations in the articles are highlighted as paragraphs in the Criminal Codes of Japan, France, and the Republic of Iran.

- as a structural component that differentiates the article into independent norms is a paragraph in the Criminal Codes of the Republic of Poland, Germany, Denmark, New York, and Pennsylvania.

- the legislator uses paragraph literation as a compositionalgraphic device in the Criminal Code of China.

Differentiation of an article into its constituent parts using structural components increases the consistency of the presentation of regulatory prescriptions. Compositionally, the criminal law is a special text, which must have digital and alphabetic literation of articles, divided into parts, as well as the division of criminal law provisions using paragraphs (Hewitt et al., 2020). Multi-stage gradation of articles improves the quality of the interpretation of criminal law orders by updating (highlighting) the most important segments of the normative text, which contributes to increasing the efficiency of law enforcement practice. 
4. Content of legislative mandates. The content of criminal legislative mandates should: firstly, accurately express the meaning of criminal law concepts; secondly, adequately reflect the behavior model of actors of the norm; thirdly, consistently set out in the normative text; fourthly, have the maximum clarity, distinctness, and consistency.

\section{Discussion}

Following the guidelines of the legislative design technique, the provisions of legislative textual criticism, and the position of German researchers of criminal law-making (Hernández, 2019), the following can be noted:

- firstly, there are no definitive norms on complicity in the institutions of complicity in the studied criminal codes, which excludes the possibility of clearly expressing the meaning of this concept and reflecting the signs of the existing criminal law phenomenon known as complicity in a crime.

- secondly, there is no uniform differentiation of accomplices into types in the legislation. The Criminal Codes of Germany, the Republic of Bulgaria, and Japan recognize the perpetrator, instigator, and accessory as accomplices; the Criminal Codes of France and Spain - the perpetrator and other accomplices; the Criminal Code of the Netherlands - the main participants and accomplices; the Criminal Code of the Republic of Poland - the perpetrators, organizers, instigators, and accomplices. The Criminal Code of the Republic of Iran recognizes accessories and three categories of accomplices; the Criminal Code of China singles out the main criminal as accessories, which includes the organizer, the leader of the criminal group, the person playing the main role in a joint crime, instigator, and accomplice. Accomplices in the criminal laws of the US states are the person guilty of a crime, as well as another person (New York), an accomplice of another and a person guilty of incitement (Pennsylvania).

The absence of the term's "perpetrator", "instigator", and "accomplice" in several criminal codes of states reduces the quality of legislative texts. However, the legislative technique obliges lawmakers to fully use legal terminology, since, with the help of the corresponding term, the concept is fixed as a legal category, which is later used in theory and practice.

- thirdly, prescriptions on complicity in the codes of states for the most part do not contain a direct indication of the form of the guilt of persons committing a crime with complicity and the subjective side of the crime, as the legislators imply that complicity 
is committed with intent. Along with this approach, the criminal codes of some states contain provisions recognizing the possibility of complicity with an unintentional form of guilt (the Criminal Code of the Republic of Poland) and complicity through negligence (the Criminal Code of Denmark).

- fourthly, German and American legislation contains specific provisions on liability for attempted complicity. Thus, the Criminal Code of the Federal Republic of Germany distinguishes four types of attempted complicity: 1) an attempt to persuade another person to commit a crime; 2) an attempt to incite to commit a crime; 3) expression of readiness to commit a crime; 4) acceptance of a proposal to commit a criminal offense. The legislator criminalizes attempted incitement and attempted execution by highlighting these types of assassination. When an attempt is made to persuade or incite another person to commit a crime, an attempt at incitement takes place. Expression of readiness to commit a crime or acceptance of an offer to commit a criminal offense is punished for attempted execution.

In addition to recognizing the possibility of attempted complicity, the German legislator formulated a rule on the voluntary refusal of attempted complicity. The law has identified three categories of persons who can be recognized as voluntarily renouncing attempted complicity (Vaughn, 2020). However, the law establishes the punishment of a person for an unfinished crime, if the person has not made voluntary and persistent efforts to prevent the crime. The Criminal Code of the Republic of Poland also contains a provision based on which a person can be prosecuted for attempted incitement or aiding if they tried to commit a criminal act. If such an attempt was not carried out, then extraordinary mitigation of punishment is applied to the person or the punishment is not imposed at all;

- fifthly, legislators formulate instructions on the influence of the personal qualities of an accomplice on the exclusion, reduction, or increase of the punishment (the Criminal Codes of the Federal Republic of Germany, Denmark, the Republic of Bulgaria, the Republic of Poland, Japan, and others). Personal qualities are considered only concerning the owner of these qualities. However, individual national codes, for example, Art. 65 of the Criminal Code of Japan, allow spreading the influence of personal qualities on the amount of punishment of accomplices who do not possess the specified qualities.

- sixthly, several codes (the Criminal Codes of Poland, Bulgaria, and Denmark) contain instructions on the voluntary refusal of accomplices to a crime. Based on the law, an accomplice is not 
subject to a penalty when committing such anti-criminal actions as refusing to continue participating in the commission of a crime and preventing the occurrence of a criminal result. At the same time, the Danish and Polish legislators address the prescription to all accomplices, the Bulgarian - to the instigator and accomplice.

- seventhly, the considered institutions of complicity contained in the criminal codes do not prescribe the forms of group commission of a crime. Criminal conspiracy orders are only available in the Pennsylvania Criminal Code.

- eighthly, the legislation lacks uniformity in regulating the punishability of the actions of accomplices. The German legislator prescribes that each accomplice should be charged with special personal characteristics when imposing punishment. The same penalty is imposed on the perpetrator and other accomplices following the Criminal Codes of France and Denmark. The institution of the complicity of the Criminal Code of Spain does not contain normative prescriptions on the punishment of the actions of accomplices. According to the Criminal Code of the Republic of Bulgaria, punishment is imposed taking into account the nature and degree of everyone's participation in achieving a criminal result. The Polish legislator obliges the court to punish within the limits of intent and unintentional fault of the accomplices of a criminal act (Aizpurua et al., 2020). The Criminal Code of Japan provides for equal liability of the perpetrator and the instigator; the punishment for the accomplice is lighter than for the perpetrator. The law of the Republic of Iran considers the commission of a crime by two or more persons to be an aggravating circumstance. Each perpetrator is given an equal amount of punishment. Along with punishment, an accomplice may be subject to disciplinary measures, and they are held accountable even if the perpetrator is not subject to criminal liability by virtue of the law. The Criminal Code of China contains privileged prescriptions providing for the imposition of punishment on an accomplice, in contrast to the main criminals (Evans et al., 2021).

An analysis of the criminal law norms of the codes of some states, taking into account the requirements of legislative technology, allows noting that legislators, in the presence of fundamental theoretical developments in the technique of constructing norms, do not fully embody them in laws. This is especially evident in the absence of definitions and uniform terms, the formulation of titles, and the compositional-graphic construction of the normative text (Ramakers et al., 2020). At the same time, theorists of the German legislative technique believe that the structure of a normative text is determined by its content and conceptual definitions. Indeed, the 
norms - definitions make it possible to clarify the complexity of normative prescriptions governing criminal law relations. Legislative definitions should be considered as the fundamental core of the set of legal norms that form the criminal law institution of complicity in a crime.

Legislative technicians guide rule-makers along the path of eliminating long and complex legal structures (Durrant, 2020). As a general rule, they should be divided into separate short sentences, since such a construction greatly facilitates the perception of the normative text. Despite the existing rules, elongated structures are found in the legislative texts of the Criminal Codes of France, Denmark, Australia, Iran, and others.

The goal of the law's creators should be clear to everyone; the accessibility and clarity of the text are assessed according to the following criteria: simplicity, brevity, clarity, systematicity, and consistency, as well as clarity, distinctness, accuracy, certainty, optimal capacity, and compactness of legislative formulations. However, these criteria are not always implemented in criminal and penal codes. In particular, the brevity and clarity of the prescriptions are absent in the Criminal Codes of France, Bulgaria, and Iran; the systematic nature of the Criminal Codes of the Netherlands and Denmark is violated; the sequence of the presentation of regulatory prescriptions in the Criminal Code of Denmark is not always observed; the titles of the paragraphs do not correspond to the text of the criminal law orders in the Criminal Code of Pennsylvania.

\section{Conclusion}

Based on the results of the study, the following conclusions can be drawn:

- the inclusion of rules on complicity in other criminal law institutions is an unjustified construction technique.

- the lack of a title complex in the institution of complicity reduces the quality level of this institution.

- the presence of definitive norms in the institution of complicity significantly improves its quality.

- differentiation of partners in crime should not be excessive and arbitrary.

- the norms on attempted complicity in a crime increase the preventive potential of criminal legislation.

Legislative definitions should be considered as the fundamental core of the set of legal norms that form the criminal law institution of complicity in a crime. 
Also, the content of criminal law prescriptions should: firstly, accurately express the meaning of criminal law concepts; secondly, adequately reflect the behavior model of actors of the norm; thirdly, be consistently stated in the normative text; fourthly, have the maximum clarity, distinctness, and consistency.

\section{Acknowledgment}

The publication was prepared as part of the state assignment for 2020 . "Transformation of private and public law in the context of the evolving personality, society, and state" (No. 0851-2020-0033).

\section{Bibliographic References}

AIZPURUA, Eva; APPLEGATE, Brandon; BOLIN, Riane; VUK, Mateja; OUELLETTE, Heather M. 2020. "The sins of the child: Public opinion about parental responsibility for juvenile crime" In: Children and Youth Services Review. Vol. 114(C), 105023.

BODUSZEK, Daniel; DEBOWSKA, Agata; SHARRATT, Kathryn; MCDERMOTT, Danielle; SHERRETTS, Nicole; WILLMOTT, Domonoc; POPIOLEK, Katarzyna; HYLAND, Philip. 2020. "Pathways between types of crime and criminal social identity: A network approach" In: Journal of Criminal Justice. Available online. In: https://www. sciencedirect.com/science/article/abs/pii/Soo47235220302440.

DURRANT, Russil. 2020. "Evolutionary theory and the classification of crime" In: Aggression and Violent Behavior. Available online. In: https:// www.sciencedirect.com/science/article/abs/pii/S1359178920301531. Consultation date: 10/09/2020.

EVANS, Caroline; STALKER, Katie Cotter; BROWN, Mary Ellen. 2021. "A systematic review of crime/violence and substance use prevention programs" In: Aggression and Violent Behavior. Vol. 56, 101513.

FERNÁNDEZ-CAMPOY, Juan Miguel; AGUILAR-PARRA, José Manuel. 2017. "Study to Investigate the Links between Crimes Committed by Youth Offenders and the Nature of their Migratory Movements" In. Procedia Social and Behavioral Sciences. Vol. 237, pp. 505-510.

GUNADI, Christian. 2020. "Does immigrant legalization affect crime? Evidence from deferred action for childhood arrivals in the United States" In: Journal of Economic Behavior \& Organization. Vol. 178, pp. 327-353. 
Gennady Nazarenko, Alexandra Sitnikova y Andrey Baybarin

530

Institution of Complicity in a Crime: Comparative-Legal Interpretation

HERNÁNDEZ, Wilson. 2019. "Do criminal justice reforms reduce crime and perceived risk of crime? A quasi-experimental approach in Peru" In: International Review of Law and Economics. Vol. 58(C), pp. 89-100.

HEWITT, Ashley; CHOPIN, Julien; BEAUREGARD, Eric. 2020. "Offender and victim 'journey-to-crime': Motivational differences among stranger rapists” In: Journal of Criminal Justice. Vol. 69(C), 101707.

KIRILLOVA, E.A; BLINKOV, O.E; OGNEVA, N.I; VRAZHNOV, A.S; SERGEEVA, N.V. 2020. "Artificial intelligence as a new category of civil law" In: Journal of Advanced Research in Law and Economics. Vol. 11, No. 1, pp. 91-98.

RAMAKERS, Anke; AALTONEN, Mikko; MARTIKAINEN, Pekka. 2020. "A closer look at labor market status and crime among a general population sample of young men and women" In: Advances in Life Course Research. Vol. 43, 100322.

SUONPÄÄ, Karoliina; AALTONEN, Mikko; VAN DER GEEST, Victor. 2020. "Crime and income trajectories preceding lethal and non-lethal violence" In: Journal of Criminal Justice. Vol. 68.

TRONCOSO, Fredy; WEBER, Richard. 2020. "Integrating relations and criminal background to identifying key individuals in crime networks" In: Decision Support Systems. Vol. 139.

VAUGHN, Paige E. 2020. "The effects of devaluation and solvability on crime clearance” In: Journal of Criminal Justice. Vol. 68(C), 101657. 

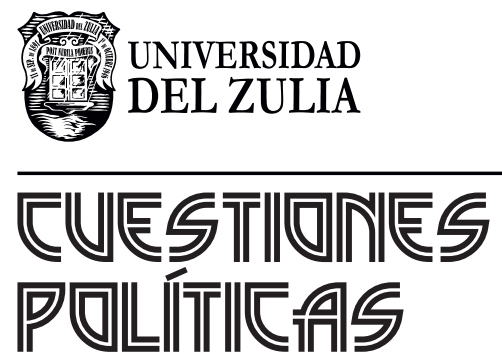

Vol.39 No 68

Esta revista fue editada en formato digital y publicada en enero de 2021, por el Fondo Editorial Serbiluz, Universidad del Zulia. Maracaibo-Venezuela 